\title{
KINERJA ORGANISASI PADA INEKSISTENSI KOPERASI DI KOTA BLITAR
}

\author{
Aris Sunandes \\ Universitas Islam Balitar \\ e-mail : arissunandes@unisbablitar.ac.id
}

\begin{abstract}
ABSTRAK
Eksistensi koperasi merupakan keberadaan koperasi dalam jangka panjang, penelitian ini bertujuan untuk mengetahui faktor-faktor penyebab tidak eksisnya koperasi ditinjau dari kinerja organisasi pada koperasi di Dinas Koperasi dan UMKM Kota Blitar. Metode penelitian yang digunakan kualitatif serta tipe eksploratif, hasilnya adalah koperasi dengan faktor masukan diketahui koperasi mempunyai keterbatasan dalam penyediaan barang atau jasa sebagai input, faktor keluaran koperasi menghasilkan barang dan jasa dengan kualitas di bawah standart. Faktor hasil koperasi menghasilkan barang atau jasa yang kurang fokus pada tujuan akhir yaitu sisa hasil usaha atau laba. Koperasi kurang mampu mencatatkan kegiatan dan mengelola keuangan, pengunaan teknologi kurang, manajemen produksi, serta Skill. Dampak penyebab tidak eksis koperasi Kota Blitar adalah input tidak tersedia, output yang tidak sesuai pasar, outcomes tidak eksis hingga kini karena faktor internal dan eksternal yang pada umumnya terjadi karena terbatasnya sumber daya dan pasar yang kurang mendukung.
\end{abstract}

\section{PENDAHULUAN}

Koperasi merupakan salah satu sektor ekonomi selain sektor riil dan pemerintah, yang dari masing-masing sektor tersebut memilki peran masingmasing dalam pertumbuhan ekonomi suatu negara khususnya di Indonesia. Seiring dalam perekembangannya, koperasi masih belum mampu berperan banyak dalam memberikan kontribusi yang signifikan pada economic growth. Beberapa statemen memberikan indikasi bahwa Indonesia seharusnya lebih giat lagi menumbuhkan koperasi dalam pembangunannya (Kadir dan Yusuf, 2012), pada kenyataannya yang terjadi adalah UUD 1945 memberikan arahan pada bangsa Indonesia bahwa koperasi merupakan salah satu bentuk badan usaha yang sesuai dengan kultur dan budaya serta situasi ekonomi di Indonesia, sehingga koperasi perlu untuk didorong agar berkembang dan kuat dalam menghadapi persaingan di pasar yang mana arus transaksi global sudah tidak bisa lagi dibendung, dengan adanya revolusi industri 4.0 .

Pembangunan koperasi yang kuat lebih tidak saja bisa dilaksanakan oleh pihak koperasi saja, akan tetapi pihak-pihak di luar koperasi juga mempunyai andil yang besar dalam menumbuh-kembangkan koperasi. Anggota koperasi mempunyai peran besar dan mampu memiliki kekuatan suara dalam menentukan langkah dan strategi koperasi untuk mampu bertahan dalam menghadapi situasi ekonomi apapun. Sebagian besar anggota koperasi ada yang kurang paham tentang batasan dan nilai-nilai serta prinsip koperasi, sedangkan hal tersebut merupakan jati diri koperasi. Dalam keadaan kurang paham tersebut dapat 
mengubah arah koperasi dan bahkan bentuk kopersi yang kurang pada tempatnya. Kekeliruan dalam memahami manajemen dan prinsip-prinsip dalam berorganisasi dan membangun serta mengembangkan koperasi hanya sekedar wacana dengan berbagai pendekatan makro ekonomi, politik dan budaya (Ibnoe Soedjono, 2003)

Kota Blitar merupakan salah satu kota di Indonesia yang getol dalam melakukan pembinaan dan pengadaan UMKM bagi masyarakatnya. UMKM di Blitar mempunyai komoditi yang cukup meyakinkan, dan menghasilkan produk yang beragam, mulai produk pangan, batik, sampai kerajinan tangan. Dan peranan koperasi dalam membantu kelancaran UMKM di Kota Blitar ini juga sangat penting, karena memang koperasi lah yang mayoritas menjadi sarana untuk memasarkan produk-produk tersebut ke masyarakat umum. Akan tetapi, pentingnya keberadaan koperasi bagi masyarakat dan sebagai faktor pendukung majunya UMKM ini, tidak begitu disadari oleh masyarakat dan pemerintah setempat. Tercatat bahwa dari 312 koperasi yang ada, 75 koperasi mengalami tidak eksis , dengan kata lain, tidak bisa berfungsi sebagaimana mestinya. Hal ini juga dibenarkan oleh Kepala Dinas Koperasi dan UKM kota Blitar, dikutip dari radio bonafit kota Blitar, meyebutkan bahwa, " Hampir 24\% diantaranya atau sebanyak 75 koperasi di Kota Blitar dinyatakan tidak aktif” (Febriantika, 2016).

Berdasar pada pengamatan dan uraian sebelumnya, koperasi di Indonesia khususnya di Kota Blitar harus lebih selalu berkembang dan eksis dalam menghadapi siatuasi apapun. Perlu disadari baik oleh pengurus koperasi dan anggotannya untuk lebih memahami arti eksistensi dalam arti luas ketimbang hanya mengedepankan keuntungan jangka pendek yang dapat menjerumuskan koperasi ke arah kebangkrutan, oleh karena itu penelitian ini memiliki rumusan permasalahan: faktor-faktor apa yang menyebabkan tidak eksisnya koperasi sehubungan dengan kinerja organisasi pada dinas koperasi Dan UMKM di kota Blitar. Tujuan dari penelitian ini adalah untuk mengetahui faktor-faktor penyebab tidak eksisnya koperasi ditinjau dari kinerja organisasi pada dinas koperasi Dan UMKM di kota Blitar.

Kinerja atau performance adalah merupakan pencapaian baik oleh individu maupun kelompok atas hasil kerja atau luaran yang setiap saat selalu diharapkan oleh semua pihak dalam organisasi. Kinerja menjadi hal penting karena, dengan kinerja dapat diketahui usaha-usaha yang telah dilakukan baik oleh indivu maupun kelompok kerja dalam mencapai tujuan yang telah digariskan oleh pemberi kerja sesuai dengan target kerja. Selain itu kinerja juga merupakan salah satu indikator untuk mengetahui kesuksesan kerja baik dalam kelompok maupun individu dalam menyelesaikan seluruh kegiatan kerjanya. Keban (2004), kinerja adalah definisi dari performance atau dapat diartikan sebagai unjuk kerja, prestasi atau penampilan. Istilah kinerja mengemuka pengertian job performance dengan kata lain penampilan nyata berupa hasil kerja merupakan keinginan awal yang hendak dicapai. (Mangkunegara, 2008). Apabila lebih diperjelas lagi bahwa kinerja merupakan upaya tolok ukur, atau prestasi dari pekerjaan yang dilakukan baik secara individu maupun secara kelompok. Kinerja tersebut dari hari ke hari diharapkan semakin meningkat menuju lebih baik lagi.

Keban (2004) penilaian hasil kerja dapat dilakukan berdasarkan kinerja individu, kinerja kelompok, kinerja organisasi dan kinerja program. 
a. Kinerja individu, menjelaskan kemampuan seseorang untuk dapat menyelesaikan tugas pokok yang telah menjadi bagian dari tugas tujuan yang telah ditetapkan oleh organisasi.

b. Kinerja kelompok, menjelaskan hasil yang diperoleh baik oleh kelompok atau organisasi untuk menyelesaikan pokok yang merupakan tugas organisasi dan merupakan tujuan yang telah ditetapkan oleh organisasi.

c. Kinerja organisasi, menjeaskan pencapaian tingkat keberhasilan satu kelompok atau organisasi yang telah dicanangkan dalam visi, misi dan tujuan dari organisasi.

d. Kinerja program, menjelaskan capaian-capaian dari suatu kegiatan atau program-program yang telah dilaksanakan sesuai dengan tujuan program yang hendak dicapai.

Atmosoeprapto (Nogi, 2005) ada dua faktor yang mampu mempengaruhi kinerja organisasi dalam hal ini dibedakan kedalam dua faktor yaitu internal dan eksternal, dengan rincian sebagai berikut:

a. Faktor eksternal:

1) Faktor politik,

Merupakan faktor yang mampu mempengaruhi kestabilan organisasi untuk melakukan karya secara maksimal, yaitu sehubungan dengan pengaruh pada faktor ketertiban dan faktor keamanan dalam menjamin keseimbangan dalam kekuasaan negara.

2) Faktor ekonomi,

Merupakan faktor yang mampu mempengaruhi dan menggerakan berbagai sektor lain dalam suatu pola ekonomi dalam sistem skala besar, faktor ini mepengaruhi secara langsung pada tingkat pendapatan yang akan mengakibatkan perubahan daya beli.

3) Faktor sosial,

Merupakan faktor yang mempengaruhi sudut pandang masyarakat terhadap etos kerja sehingga sangat berguna bagi peningkatan kinerja dalam organisasi, fokus orinetasi ini adalah nilai-nilai di dalam masyarakat yang akan semakin berkembang.

b. Faktor internal, yang terdiri dari :

1) Tujuan organisasi, merupakan sesuatu yang akan diproduksi dan dihasilkan oleh organisasi dalam memwujudkan keinginannnya.

2) Struktur organisasi, merupakan hasil rekayasan model antara fungsi yang perlu untuk digerakkan dengan unit organisasi pada rangkaian formal organisasi.

3) Sumber Daya manusia, merupakan faktor penggerak organisasi yang akan memberikan kualitas pelayanan dan pengelolaan organisasi bagi anggotaanggotanyasecara keseluruhan.

4) Budaya Organisasi, merupakan identitas organisasi dan style organisasi yang menempatkan pola kerja standart yang merupakan ciri khas organisasi tersebut.

Dari faktor-faktor tersebut, diketahui bahwa, jika faktor yang mempunyai pengaruh paling dominan dalam suatu kinerja organisasi adalah faktor internal (faktor yang berasal dari dalam organisasi tersebut) dan faktor eksternal (faktor 
yang berasal dari luar organisasi yang bersangkutan). Kinerja organisasi adalah gambaran tentang hasil akhir organisasi untuk mendapatkan tujuan yang sebenarnya akan mempengaruhi pada semua sumber daya yang ada dalam lingkungan internal organisasi. Sumber daya tersebut adalah fisik misalnya sumber daya manusia ataupun non fisik adalah kebijakan, informasi dan peraturan, maka agar mampu memahami suatu kinerja organisasi adalah dengan terlebih dahulu mengenal dan paham tentnag faktor-faktor tersebut. Perlu diketahui, perbedaan sumber daya dan faktor internal dan faktor eksternal setiap organisasi, hal ini akan meyebabkan perbedaan hasil penilaian dan pencapaian setiap kinerja suatu organisasi.

Kinerja organisasi juga memiliki indikator-indikator tertentu, indikator kinerja ini berguna untuk menilai atau mengukur tingkat pencapaian kinerja organisasi tersebut. Selain itu adanya perbedaan-perbedaan penilaian dan pencapaian hasil kinerja organisasi ini meyebabkan orang bingung untuk menilai secara pasti bagaimana kinerja suatu organisasi tersebut, maka dari itu adanya indikator yang menjadi patokan berhasil atau tidaknya suuatu kinerja sangatlah penting. Bastian menyebutkan bahwa ada baiknya jika kinerja organisasi memiliki dan memiliki indikator sebagai berikut:

a. Indikator masukan (inputs) adalah segala sesuatu yang dibutuhkan agar organisasi mampu menghasilkan produknya, baik barang atau jasa yang meliputi sumber daya manusia, informasi, kebijakan dan sebagainya.

b. Indikator keluaran (outputs) adalah sesuatu yang diharapkan langsung dicapai dari suatu kegiatan yang berupa fisik ataupun nonfisik.

c. Indikator hasil (outcomes) adalah segala sesuatu yang terkait dengan tujuan akhir dari pelaksanaan kegiatan.

d. Indikator dampak (impacts) adalah pengaruh yang ditimbulkan baik positif maupun negatif pada setiap tingkatan indikator berdasarkan asumsi yang telah ditetapkan. (Bastian, 2001)

Gambar 1.

Konsep Kinerja Koperasi, Kinerja Organisasi Koperasi Ineksistensi

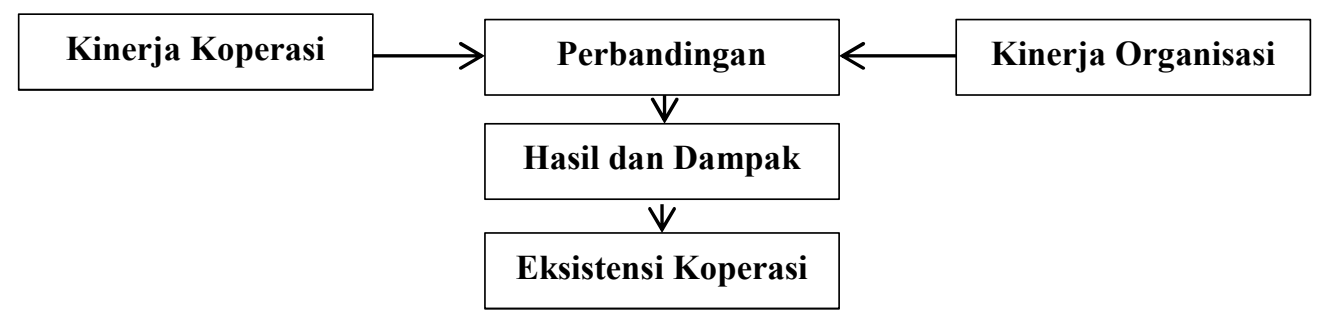

\section{METODE PENELITIAN}

Metode penelitian adalah kualitatif. Penelitian kualitatif lebih mementingkan proses daripada hasil yang akan dicapai, seting obyek penelitian secara alami sehingga membentuk satu kesatuan utuh dan mengandalkan manusia yang merupakan satu-satunya alat penelitian, keabsahan data menggunakan triangulasi sehingga hasil penelitian merupakan kesepakatan kedua belah pihak antara subyek dengan peneliti (Moleong, 2004). Lokasi penelitian di Kota Blitar dan pada dinas Koperasi dan UKM Kota Blitar pada koperasi-koperasi yang 
sudah tidak eksis dengan jumlah 75 koperasi di tahun 2017. Kountur (2009) pengumpumpulan data dengan peneliti sebagai instrumen, maka digunakan teknik wawancara atau observasi dalam mengumpulkan data-data dari sumber data primer. Untuk menggali informasi yang lebih dalam indepth interview peneliti juga melakukan wawancara sebagai alatnya (Sutopo, 2002). Definisi konseptual dari kinerja organisasi adalah indikator-indikator tertentuyang dipergunakan untuk menilai atau mengukur tingkat kinerja yang telah dicapai oleh organisasi dalam periode tertentu. Eksistensi koperasi adalah keberadaan atau tetap berlangsungnya organisasi koperasi hingga saat ini.

Untuk meningkatkan kredibilitas data yang diperoleh selama proses penelitian dilakukan dengan teknik triangulasi. Triangulasi adalah teknik pemeriksaan keabsahan data yang memanfaatkan sesuatu yang lain diluar data itu untuk keperluan pengecekan atau sebagai pembanding terhadap data itu. Denzin membedakan empat macam triangulasi sebagai teknik pcmeriksaan yang memanfaatkan penggunaan sumber, metode, penyidik dan teori. (Moleong, 2004). Analisa data dengan menggunakan tiga elemen dasar yang telah dipahami oleh peneliti yaitu reduksi data atau eliminasi data, penyajian data dan pengambilan kesimpulan atau tahap akhir yaitu verifikasi.

\section{Perbandingan Kinerja Organsisasi Dengan Kinerja Koperasi dengan Indikator Output}

Output suatu perusahaan yang bergerak di bidang produk dan jasa dapat berupa barang dan jasa yang dihasilkan dari proses produksi oleh koperasi. Dengan pertanyaan tentang : Bagaimana tentang luaran selama ini dengan indikator barang dan jasa yang dihasilkan dari proses produksi yang dimiliki oleh koperasi. Indikator keluaran (output) hasil penelitian diketahui bahwa koperasi menghasilkan barang dan jasa dengan kualitas di bawah standart, faktor-faktor penyebab tidak eksis koperasi kota Blitar adalah:

a. Pemasaran sulit, Faktor internal sumber daya modal dan faktor eksternal sosial. Koperasi dalam memasarkan barangnya mempunyai kesulitan pada faktor distribusi barang, tidak memperhatikan kebutuhan dan keinginan konsumen serta teknik pemasaran yang masih tradisional. Barang yang dipasarkan oleh anggota koperasi juga tidak memperhatikan kebutuhan dan keinginan konsumen sehingga ketika barang dibawa ke pasar, tidak begitu banyak yang membutuhkan. Teknik pemasaran yang sederhana lebih memperburuk situasi pemasaran anggota koperasi.

b. Area pemasaran terbatas, faktor eksternal ekonomi dan sosial.Keterbatasan sarana untuk pemasaran sehingga anggota koperasi hanya mampu memasarkan barangnya pada daerah sekitar saja. Area pemasaran yang terbatas juga membawa pengaruh menurunnya tingkat penjualan dan omset penjualan.

c. Pesaing produk sejenis banyak, faktor eksternal ekonomi. Persaingan dengan perusahaan atau produk lain selain koperasi juga sering memicu penurunan omset penjualan. Persaingan terjadi pada level harga, koperasi tidak mampu menekan harga karena ongkos produksi yang tinggi, oleh karena itu perlu koperasi perlu diberikan wadah dari pemerintah untuk mempromosikan 
berang dagang. Kualitas produk yang diproduksi oleh koperasi juga relatif sedang sehingga ketika ada pesaing dengan harga yang sama dengan kualitas produk yang lebih baik, maka konsumen cenderung untuk memilih produk yang ditawarkan oleh pesaing.

d. Adanya barang subtitusi, faktor eksternal ekonomi.Adanya barang pengganti (subtitusi) semakin bertambah di pasar, apabila hal ini tidak segera melakukan diversifikasi produk dan anggota koperasi tidak mampu membendung serangan dari barang pengganti ini, maka barang yang dipasarkan tidak mempunyai nilai tawar sehingga tidak mendapat perhatian dari konsumen. Pada akhirnya akan menambah penumpukan barang yang tidak laku.

e. Teknologi masih sederhana, faktor internal sumber daya kapital. Kemajuan teknologi juga membawa dampak yang baik dan buruk bagi koperasi, dampak yang baik dirasakan apabila anggota koperasi mampu memanfaatkan seluruh potensi untuk memajukan koperasinya, dampak buruknya adalah dengan adanya teknologi baru.

f. Brand operasi yang kurang dikenal, faktor internal sumber daya manusia dan faktor eksternal ekonomi dan sosial. Merek merupakan salah satu hal yang menjadi sangat penting ketika seorang konsumen harus mengenali sesuatu barang dengan mengerti kualitas yang ada di dalamnya, dengan adanya merek, maka konsumen lebih tidak hanya mengenal akan tetapi menaruh kepercayaan mereka pada merek yang merek gunakan. Merek yang dikenal dengan baik dan mempunyai persepsi yang baik di benak konsumen, akan dikenal dengan baik oleh konsumen dan begitu pula sebaliknya, apabila tidak dikenal, maka akan sulit bagi produsen untuk memberikan atau memposisikan produk yang mereka buat di mata konsumen.

\section{Perbandingan Kinerja Organsisasi Dengan Kinerja Koperasi dengan Indikator Outcome}

Outcome suatu perusahaan yang bergerak di bidang produk dan jasa hasil yang dicapai oleh perusahaan yaitu dengan indikator pendapatan dikurangi dengan pengeluaran sehingga menghasilkan selisih positif berupa laba dari koperasi. Dengan pertanyaan tentang : Bagaimana tentang kelancaran tentang laba yang diperoleh dari perencanaan (anggaran misalnya), pencatatan tentang pendapatan dan pengeluaran dan pembukuan koperasi. Indikator hasil (outcomes) hasil penelitian diketahui bahwa koperasi dalam menghasilkan barang atau jasa kurang fokus pada tujuan akhir yaitu sisa hasil usaha atau laba, faktor-faktor penyebab tidak eksis koperasi kota Blitar adalah:

a. Kurang mampu membukukan kegiatan (laporan keuangan). Faktor internal sumber daya manusia. Kebanyakan koperasi di wilayah kota Blitar memiliki kemampuan terbatas dalam melaksanakan tata kelola di bidang pencatatan transaksi yang mereka lakukan, sehingga kegiatan pembukuan juga terganggu.

b. Kurang mampu mengelola keuangan (manajemen keuangan). Faktor internal sumber daya manusia dan struktur organisasi. Faktor internal struktur dan sumber daya manusia. Penglolaan keuangan tidak mudah dan tidak semua orang dapat melakukkan dengan baik, sebenarnya koperasi boleh mempekerjakan atau menunjuk salah satu orang sebagai manager keuangan, 
penunjukkan ini biasanya disertai dengan gaji yang relatif tinggi, koperasi rata-rata kurang mampu untuk menggaji manager keuangan.

c. Pengunaan teknologi kurang (manajemen operasional). Faktor internal sumber daya kapital dan budaya organisasi.Pengelolaan produksi mulai dari input proses dan output, merupakan salah satu rangkaian yang tidak terputus dan membentuk suatu sistem produksi yang akan menghasilkan produk dan jasa yang berkualitas yag memiliki daya saing bagi koperasi. Kebanyakan koperasi di kota Blitar, operasional masih menggunaka teknologi yang sederhana dan belum menyentuh teknologi maju, oleh karena itu hasil yang didapat pun juga masih belum maksimal dengan kualitas mutu yang berdaya saing rendah.

d. Kurang mampu mengelola produk (manajemen produksi). Faktor internal sumber daya manusia. Manajemen produksi tidak hanya menyangkut input proses dan output saja akan tetapi bagaimana mengoptimalkan seluruh potensi yang ada dalam proses produksi untuk menghasilkan proses produksi yang optimal, tidak terlalu sedikit dan tidak terlalu berlimpah, seharusnya koperasi mampu mengkombinasi masukan dan keluaran sehingga didapat hasil yang optimal, hal ini tidak dimiliki oleh koperasi di kota Blitar.

e. Kurang mampu membuat anggaran (perencanaan). Faktor internal sumber daya manusia dan tujuan perusahaan.Perencanaan secara kuantitatif atau rencana perusahaan yang dicetuskan dalam bentuk angka disebut dengan anggaran, koperasi rata-rata tidak mempunyai perencanaan yang fokus pada masa depan koperasi. Anggaran dibuat untuk dilaksanakan dan diawasi serta dikendalikan, apabila koperasi tidak mempunyai perencanaan, maka koperasi akan berjalan tidak tentu arah, oleh karena itu sulit untuk dikendalikan, akibatnya koperasi mudah goyah dan berjalan tidak sesuai dengan AD dan ART yang telah disepakati.

f. Keterbatasan pengetahuan (Skill). Faktor internal sumber daya manusia, budaya organisasi dan tujuan perusahaan. Skil merupakan salah satu kemampuan yang tidak bisa dimiliki dengan sekejap, koperasi di kota Blitar, rata-rata dibentuk oleh sekumpulan orang-orang yang mempunyai pengetahuan terbatas pada bidang bisnis.

\section{Perbandingan Kinerja Organsisasi Dengan Kinerja Koperasi dengan Indikator Impact}

Impact suatu perusahaan yang bergerak di bidang produk dan jasa hasil yang dicapai oleh perusahaan yaitu dengan indikator kelancaran dalam hal input, proses produksi dan luaran dari perusahaan. Dengan pertanyaan tentang : Bagaimana tentang kelancaran proses secara umum dan menyeluruh apabila ditinjau dari sisi masukan, proses dan luaran perusahaan yang selama ini telah dijalankan oleh koperasi. Indikator dampak (impact) hasil penelitian merupakan pengaruh yang ditimbulkan baik positif maupun negatif pada setiap tingkatan indikator berdasarkan asumsi yang telah ditetapkan, diketahui indikator yang lain dari kualitas organisasi adalah input, output dan outcomes bahwa faktor-faktor penyebab tidak eksis koperasi kota Blitar adalah:

1. Input (Input tersedia, input tidak tersedia) 
Faktor internal sumber daya alam, sumber daya manusia dan sumber daya kapital dan faktor eksternal ekonomi. Koperasi rata-rata kekurangan sumber daya alam, sumber daya tenaga kerja dan sumber daya modal. Oleh karena itu banyak koperasi yang tidak eksis karena dari dalam operasi itu sendiri, sedangkan dari faktor eksternal terdapat faktor ekonomi, hal ini meliputi pasar, pesaing dan suhu politik dan ekonomi makro yang kurang mendukung untuk tumbuh kembangnya koperasi.

2. Output (sesuai pasar dan tidak sesuai pasar)

Faktor internal tujuan koperasi merupakan faktor eksternal yaitu ekonomi dan sosial yaitu tingkat keterbatasan ekonomi dan lingkungan sosial yang kurang memahami proses bisnis secara keseluruhan. Sehingga dari segi faktor internal yang terjadi adalah kegagalan koperasi untuk mencapai tujuan perusahaan, hal inilah yang menyebabkan tidak eksis nya koperasi di Indonesia.

3. Outcomes (Proses produksi, teknologi, kualitas)

Sisa hasil usaha yang merupakan tujuan keuangan dari setiap koperasi, hal ini belum tentu tercapai karena adanya keterbatasan pada tingkat sumber daya dan konsumen serta pasar baik dalam lingkup dalam dan luar organisasi.

\section{Analisis Data dan Pembahasan}

Analisis kinerja koperasi dimulai dengan analisis kinerja organisasi dibandingkan dengan kinerja koperasi. Kinerja organisasi memiliki indikatorindikator tertentu, indikator kinerja dipergunakan untuk menilai atau mengukur tingkat pencapaian kinerja organisasi tersebut. Kinerja koperasi diperoleh dari hasil wawancara yang sudah dikelompokkan untuk mengetahui perbandingan kinerja organisasi yang berkualitas dengan kinerja koperasi yang ada di Kota Blitar. Perbedaan-perbedaan penilaian dan pencapaian hasil kinerja organisasi ini menghasilkan kesesuaian dan ketidaksesuaian antara kinerja organisasi dengan kinerja koperasi. Penjelasan perbedaan kinerja organsasi dengan kinerja koperasi adalah sebagai berikut :

Tabel 1.

Perbandingan Kinerja Organsisasi Dengan Kinerja Koperasi

\begin{tabular}{|l|l|l|l|}
\hline Indikator & Kinerja Organisasi & Kinerja Koperasi & $\begin{array}{l}\text { Hasil } \\
\text { Analisis }\end{array}$ \\
\hline Masukan & $\begin{array}{l}\text { Adalah sumber-sumber } \\
\text { daya yang digunakan } \\
\text { untuk melakukan } \\
\text { proses produksi yaitu } \\
\text { informasi, sumber daya } \\
\text { manusia, kebijakan dan } \\
\text { sebagainya. }\end{array}$ & $\begin{array}{l}\text { Koperasi mempunyai } \\
\text { keterbatasan dalam } \\
\text { penyediaan barang atau jasa } \\
\text { sebagai input. Hasil temuan: } \\
\text { Material yang sulit didapat, } \\
\text { sesuai } \\
\text { kenurangan modal usaha, } \\
\text { ketrampilan dari tenaga } \\
\text { kerja dan keterbatasan } \\
\text { kinerja } \\
\text { organisasi. }\end{array}$ & \\
& sumber informasi & \\
\hline Luaran & $\begin{array}{l}\text { Adalah capaian dari } \\
\text { suatu kegiatan baik } \\
\text { bersifat fisik ataupun } \\
\text { nonfisik, yang secara }\end{array}$ & $\begin{array}{l}\text { Koperasi menghasilkan } \\
\text { barang dan jasa dengan } \\
\text { kualitas di bawah standart. } \\
\text { Hasil temuan: }\end{array}$ & $\begin{array}{l}\text { Tidak } \\
\text { sesuai } \\
\text { dengan } \\
\text { kinerja }\end{array}$ \\
\hline
\end{tabular}




\begin{tabular}{|c|c|c|c|}
\hline Indikator & Kinerja Organisasi & Kinerja Koperasi & $\begin{array}{l}\text { Hasil } \\
\text { Analisis }\end{array}$ \\
\hline & $\begin{array}{l}\text { langung merupakan } \\
\text { harapan organisasi } \\
\text { yang ini dicapai secara } \\
\text { langsung. }\end{array}$ & $\begin{array}{l}\text { Keterbatasan area } \\
\text { pemasaran maupun sulitnya } \\
\text { pemasaran, munculnya } \\
\text { perusahan dengan usaha } \\
\text { sejenis, hadirnya barang } \\
\text { pengganti, kesederhanaan } \\
\text { penggunaan teknologi, serta } \\
\text { kemampuan brand yang } \\
\text { terbatas. }\end{array}$ & organisasi. \\
\hline Hasil & $\begin{array}{l}\text { Adalah segala sesuatu } \\
\text { yang terkait dengan } \\
\text { tujuan akhir dari } \\
\text { pelaksanaan kegiatan. }\end{array}$ & $\begin{array}{l}\text { Koperasi dalam } \\
\text { menghasilkan barang atau } \\
\text { jasa kurang fokus pada } \\
\text { tujuan akhir yaitu sisa hasil } \\
\text { usaha atau laba. } \\
\text { Hasil temuan: } \\
\text { Kekurangan pada } \\
\text { pengelolaan keuangan, } \\
\text { catatan pembukuan, } \\
\text { teknologi yang digunakan, } \\
\text { manajemen produk. }\end{array}$ & $\begin{array}{l}\text { Tidak } \\
\text { sesuai } \\
\text { dengan } \\
\text { kinerja } \\
\text { organisasi. }\end{array}$ \\
\hline Impacts & $\begin{array}{l}\text { Adalah pengaruh yang } \\
\text { ditimbulkan baik } \\
\text { positif maupun negatif } \\
\text { pada setiap tingkatan } \\
\text { indikator berdasarkan } \\
\text { asumsi yang telah } \\
\text { ditetapkan. }\end{array}$ & $\begin{array}{l}\text { Dampak dari masalah input, } \\
\text { output. } \\
\text { Hasil temuan: } \\
\text { Ketersediaan input } \\
\text { kesesuaian pasar, hasil pada } \\
\text { kualitas }\end{array}$ & $\begin{array}{l}\text { Tidak } \\
\text { sesuai } \\
\text { dengan } \\
\text { kinerja } \\
\text { organisasi. }\end{array}$ \\
\hline
\end{tabular}

Perbandingan kualitas kinerja koperasi dibandingkan dengan kinerja organisasi dimulai dengan mengetahui indikator dari kualitas kinerja organisasi yang memiliki indikator yaitu masukan, luaran, hasil dan dampak. Hasil temuan ternyata koperasi yang tidak eksis mempunyai permasalahan sebagai berikut:

1. Penyebab tidak eksis dengan indikator masukan (input) hasil penelitian diketahui bahwa koperasi mempunyai keterbatasan dalam penyediaan barang atau jasa sebagai input yaitu bahan baku sulit didapat, modal kurang, tenaga kerja kurang terampil, sumber informasi yang terbatas, hasil ini tidak sesuai dengan kualitas kinerja organisasi yaitu segala sesuatu yang dibutuhkan agar organisasi mampu menghasilkan produknya, baik barang atau jasa yang meliputi sumber daya manusia, informasi, kebijakan dan sebagainya.

2. Penyebab tidak eksis dengan indikator keluaran (output) hasil penelitian diketahui bahwa koperasi menghasilkan barang dan jasa dengan kualitas di bawah standart yaitu pemasaran sulit, area pemasaran terbatas, pesaing produk sejenis banyak, adanya barang subtitusi, teknologi masih sederhana, dan brand operasi yang kurang dikenal, hasil ini tidak sesuai dengan kualitas 
kinerja organisasi yaitu sesuatu yang diharapkan langsung dicapai dari suatu kegiatan yang berupa fisik ataupun nonfisik.

3. Penyebab tidak eksis dengan indikator hasil (outcomes) hasil penelitian diketahui bahwa operasional dalam menghasilkan barang atau jasa kurang fokus pada tujuan akhir yaitu sisa hasil usaha atau laba yaitu kurang mampu membukukan kegiatan (laporan keuangan), kurang mampu mengelola keuangan (manajemen keuangan), pengunaan teknologi kurang (manajemen operasional), kurang mampu mengelola produk (manajemen produksi), kurang mampu membuat anggaran (perencanaan) dan keterbatasan pengetahuan (Skill) hasil ini tidak sesuai dengan kualitas kinerja organisasi yaitu segala sesuatu yang terkait dengan tujuan akhir dari pelaksanaan kegiatan.

4. Penyebab tidak eksis dengan indikator dampak (impact) hasil penelitian diketahui bahwa dampak dari masalah input, output yaitu input tersedia, input tidak tersedia), output (sesuai pasar dan tidak sesuai pasar), outcomes (proses produksi, teknologi, kualitas), hasil ini tidak sesuai dengan kualitas kinerja organisasi yaitu memberikan pengaruh yang ditimbulkan baik positif maupun negatif pada setiap tingkatan indikator berdasarkan asumsi yang telah ditetapkan.

\section{KIMPULAN DAN SARAN \\ Kesimpulan}

1. Hasil penelitian dengan faktor masukan (input) bahwa koperasi mempunyai keterbatasan dalam penyediaan barang atau jasa sebagai input. Faktor keluaran (output) diketahui bahwa koperasi menghasilkan barang dan jasa dengan kualitas di bawah standart pada koperasi yang tidak eksis.

2. Faktor hasil (outcomes) diketahui bahwa koperasi dalam menghasilkan barang atau jasa kurang fokus pada tujuan akhir yaitu sisa hasil usaha atau laba, koperasi mempunyai keterbatasan pembukuan, pengelolaan keuangan yang sederhana, teknologi maju belum diterapkan, operasional produksi belum dikelola dengan baik, perencanaan keuangan dengan kemampuan sederhana.

3. Dampak (impact) penyebab tidak eksisnya koperasi di Kota Blitar adalah ketersediaan input yang kurang, ketidaksesuaian dengan pasar yang dituju, hasil produksi dengan kualitas sedang, tidak tercapainya tujuan sisa hasil usaha karena faktor internal dan eksternal dengan segala sumber daya pendukung yang terbatas.

\section{Saran}

1. Bagi pihak pengurus koperasi agar mampu memberdayakan diri dengan berbagai cara untuk meningkatkan kemampuannya demi pengelolaan koperasi yang baik.

2. Pihak Dinas Koperasi dan Usaha Mikro Kecil Menengah agar sering memberikan bimbingan dan binaan serta pelatihan yang berguna bagi pengembangan pengelolan koperasi sehingga menjadi koperasi yang berkembang baik. 
3. Bagi pemerintah agar dapat memberikan bantuan modal bagi terciptanya kesinambungan bisnis dan penguatan keuangan koperasi, karena keterbatasan modal yang dimiliki dari dana simpanan wajib dan simpanan pokok.

\section{DAFTAR PUSTAKA}

Bastian, Indra., (2001). Akuntansi Sektor Publik di Indonesia, BPFE, Jogjakarta.

Bungin, Burhan., (2003). Analisis Data Penelitian Kualitatif, PT Raja Grafindo Persada, Jakarta.

Ibnoe Soedjono. Instrument pengembangan Koperasi, LSP2I, Jakarta, 2003.

Kadir, Hainim dan Yusuf, Yusbar. Optimalisasi Pengaruh Dan Eksistensi Koperasi Sebagai Soko Guru Perekonomian Daerah. Fakultas Ekonomi Universitas Riau. Pekanbaru. Jurnal Ekonomi. Vol. 20 No. 2 Hal: 1-9

Moleong, Lexy J., (2001). Metodologi Penelitian Kualitatif Edisi Revisi, PT Remaja Rosdakarya Offset, Bandung

Prawirosentono.S,(1999). Manajemen Sumber Daya Manusia, Kebijakan Kinerja Karyawan. BPFE, Jogjakarta.

Sutopo, HB., (2002). Metode Penelitian Kualitatif, UNS Press, Surakarta

Tangkilisan, Hessel Nogi S.,(2005). Manajemen Publik, Grasindo, Jakarta.

Yeremias T. Keban., (2004). Enam Dimensi Strategis Administrasi Publik: Konsep, Teori dan Isu, Gava Media, Jogjakarta. 